Diabetologia 7, 223-226 (1971)

(C) by Springer-Verlag 1971

\title{
ORIGINALS
}

\section{Effect of Phentolamine upon Insulin Secretion during Exercise}

\author{
G.R. Brisson, F. Malaisse-Lagat and W.J. Malaisse \\ Laboratory of Experimental Medicine, Brussels University, Brussels, Belgium
}

Received: January 22, 1971, accepted: April 13, 1971

\begin{abstract}
Summary. Rats were injected with guinea-pig antiinsulin serum and ${ }^{131}$ I-labelled human albumin. The amount of endogenously secreted insulin was estimated from the progressive reduction in the pool of circulating unneutralized antibodies. In animals compelled to swim, insulin secretion occured at a much lower rate than in control rats. Prior injection of phentolamine abolished the exercise-induced inhibition of insulin release. These findings support the concept that such inhibition is dure to endogenously released catecholamines.
\end{abstract}

Influence de la phentolamine sur la sécrétion d'insuline au cours de l'exercice musculaire

Resumé. Des rats reçoivent une injection d'antisérum anti-insulinique et d'albumine humaine marquée à l'iode ${ }^{131}$. Le débit sécrétoire d'insuline endogène est déduit de la réduction progressive du pool d'anticorps circulants non neutralisés. Le débit sécrétoire est nettement moindre chez les rats obligés à nager que chez les animaux témoins. Cet effet inhibiteur de l'exercice musculaire est levé par injection préalable de phentolamine. Ces données suggèrent que l'effet inhibiteur de l'effort sur la sécrétion d'insuline est secondaire à une libération de catécholamines.

Wirkung von Phentolamin auf die Insulin-Sekretion bei körperlicher Arbeit

Zusammenfassung. Bei Ratten wurden Injektionen von Antiinsulin-Serum des Meerschweinchens und von menschlichem Albumin, das mit $131 \mathrm{~J}$ gekennzeichnet war, vorgenommen. Die Menge des endogen sezernierten Insulins wurde durch die progressive Abnahme im Pool der zirkulierenden, nicht neutralisierten Antikörper bestimmt. Zwang man die Tiere zu schwimmen, so erfolgte die Insulinsekretion auf einem sehr viel niedrigerem Niveau, als bei den Kontrollratten. Vorherige Injektionen von Phentolamin hob die durch die Arbeit bedingte Hemmung der Insulinabgabe auf. Diese Befunde unterstützten die Annahme, daß eine solche Hemmung durch die endogenen sezernierten Katecholamine zustande kommt.

Key-words: Guinea-pig anti-insulin serum, insulin secretion in vivo, stress, exercise, swimming, phentolamine, catecholamines.
The influence of muscular exercise upon insulin secretion has been investigated on several occasions. In healthy patients, the level of circulating insulin is either unchanged or decreased during exercise $[1,9,11$, $13,14]$. Inhibition of insulin release in these patients might be difficult to detect since the level of circulating insulin under basal conditions is usually at the lower limit of sensitivity of most methods of plasma-insulin assay [16]. Moreover, exercise in human subjects might be associated with a decreased metabolic clearance of insulin, and this could mask inhibition of insulin release if judged solely by the level of circulating hormone [2]. A decreased concentration of circulating insulin has also been documented in rats compelled to swim [3], and monkeys exposed to a psychological stress [8]. The true rate of insulin secretion during stress and exercise has been measured in rats injected with guinea-pig anti-insulin serum (GPAIS). When these animals were forced to swim or submitted to repeated electrical shocks, the rate of insulin secretion was dramatically reduced, despite the hyperglycaemia due to the induction of insulin deficiency [18].

In these previous reports, the inhibition of insulin secretion during exercise was ascribed to a release of catecholamines, on the basis of the following obser- vations. Firstly, the level of circulating catecholamines rises during muscular exercise or stress $[4,15]$. Secondly, epinephrine and nor-epinephrine are known to inhibit insulin secretion; their inhibitory effect is apparently mediated through the activation of the alpha-adrenergic receptors of the pancreatic beta-cell [7, 10]. However, it remained to be demonstrated that the reduction of insulin secretion during exercise indeed corresponds to an adrenergic mechanism. In favour of this concept, it is shown here that phentolamine, an alpha-adrenergic blocking agent, prevents the exerciseinduced inhibition of insulin release.

\section{Material and Methods}

I. Experimental procedure. Female albino rats (Rega, Heverlee, Belgium) were fed on a standard diet (Aliments Protector, Brussels, Belgium) and had free access to food and water up to the time of use. They were divided into three groups with comparable mean body weight $(157 \pm 3 \mathrm{~g}$ for group $\mathrm{A} ; 158 \pm 2 \mathrm{~g}$ for group B; and $157 \pm 2 \mathrm{~g}$ for group $\mathrm{C}$ ). At zero time, all animals were injected intravenously (tail vein) with a same volume $(0.6 \mathrm{ml})$ of GPAIS (lot 513, prepared and 
kindly donated by Dr. P.H. Wright, Indiana University, Indianapolis, Ind.) and a trace amount of ${ }^{131} \mathrm{I}$ labelled human albumin (approximately $12 \mu \mathrm{Ci}$; CEACEN, Sorin, Italy). The amount of GPAIS injected was able to bind approximately 2.1 units bovine insulin. Blood $(0.4$ to $0.6 \mathrm{ml})$ was drawn from the severed end of the tail immediately before, and 2 and $50 \mathrm{~min}$ after this injection. For at least $30 \mathrm{~min}$ before and $50 \mathrm{~min}$ after the single intravenous injection, all the rats were kept in warm eages with free access to water, and none were handled except at times of bleeding or injection.

After the bleeding at the 50 th $\mathrm{min}$, the rats were submitted to one of the following treatments. Group $A$ : these rats were replaced in the warm cages and were not handled until they were killed at $70 \mathrm{~min}$. Group $B$ : these rats were placed in a tank of deep (18 inches) tepid $\left(31-35^{\circ} \mathrm{C}\right)$ water, and forced to swim for a period of $20 \mathrm{~min}$. After swimming for $20 \mathrm{~min}$, none of these animals showed any sign of exhaustion. Group $C$ : these rats were injected intraperitoneally at the 45 th $\mathrm{min}$ with phentolamine $(5.0 \mathrm{mg} \text {; Regitin, CIBA })^{\mathrm{1}}$, and subsequently submitted to the same treatment as immediately' separated. The plasma sugar concentration was determined by an automated microtechnique based on that described by Hoffman [5]. An aliquot $(0.1 \mathrm{ml})$ of each sample of plasma was examined for its content in 131-labelled albumin, the volume of distribution of albumin being taken as a measurement of the volume of distribution of the anti-insulin antibodies [20]. Thereafter, the same aliquot was assayed for unneutralized anti-insulin antibodies, using a method described in detail elsewhere $[17,19]$. The amount of ${ }^{25}$ I-labelled bovine insulin used for this assay was selected so that the interference of ${ }^{131}$ I did not exceed 0.5 per cent of the actual radioactivity of ${ }^{125}$ I. From the volume of distribution of the labelled albumin and the simultaneously measured concentration of unneutralized antibodies in the plasma, the total amount of unneutralized antibodies in each rat was determined at each time of bleeding. Knowing the total amount of antibodies injected and taking into account losses encountered at each bleeding, the rate of neutralization of the injected antibodies between successive bleedings was calculated, and is equated here to the rate of secretion of endogenous insulin for that

Table 1. Effect of exercise and phentolamine upon insulin secretion ${ }^{a}$

\begin{tabular}{|c|c|c|c|c|c|c|c|}
\hline Period & $\begin{array}{l}\text { Time } \\
(\min )\end{array}$ & $\begin{array}{l}\text { Rats } \\
\text { Group }\end{array}$ & $(\mathrm{N})$ & $\begin{array}{l}\text { Plasma sugar } \\
(\mathrm{mg} / 100 \mathrm{ml})\end{array}$ & $\begin{array}{l}\text { Haematocrit } \\
\text { (per cent) }\end{array}$ & $\begin{array}{l}\text { Albumin volume } \\
\text { (ml) }\end{array}$ & $\begin{array}{l}\text { Insulin secreted } \\
\text { (mUnits) }\end{array}$ \\
\hline Initial & $\begin{array}{r}0 \\
2 \\
50\end{array}$ & $\begin{array}{l}A+B+C \\
A+B+C \\
A+B+C\end{array}$ & $\begin{array}{l}(21) \\
(21) \\
(21)\end{array}$ & $\begin{array}{l}125 \pm 2 \\
131 \pm 3 \\
277 \pm 7\end{array}$ & $\begin{array}{l}43.4 \pm 0.2 \\
38.7 \pm 0.3 \\
35.9 \pm 0.6\end{array}$ & $\begin{array}{l}6.56 \pm 0.15 \\
8.33 \pm 0.24\end{array}$ & $252 \pm 27$ \\
\hline Experimental & 70 & $\begin{array}{l}\mathrm{A} \\
\mathrm{B} \\
\mathrm{C}\end{array}$ & $\begin{array}{l}(6) \\
(7) \\
(8)\end{array}$ & $\begin{array}{l}347 \pm 9 \\
259 \pm 28 \\
308 \pm 27\end{array}$ & $\begin{array}{l}31.4 \pm 1.2 \\
38.7 \pm 1.0 \\
34.3 \pm 0.9\end{array}$ & $\begin{array}{l}8.56 \pm 0.67 \\
7.68 \pm 0.63 \\
8.97 \pm 0.32\end{array}$ & $\begin{aligned} 260 & \pm 24 \\
79 & \pm 17 \\
223 & \pm 31\end{aligned}$ \\
\hline
\end{tabular}

a Mean values ( \pm SEM) for plasma sugar concentration, haematocrit, and volume of distribution of labelled albumin are stated at four times of bleeding, before $(0 \mathrm{~min})$ and after (2, 50, and $70 \mathrm{~min})$ injection of anti-insulin serum. Mean amounts of endogenously secreted insulin are stated for the whole series of animals $(N=21)$ during the initial period ( 2 to 50 min); and for the smaller groups $(N=6$ to 8$)$ during the experimental period (50 to $70 \mathrm{~min}$ ), when rats remained untreated (group A) or were compelled to swim (groups B and C). In group C, phentolamine (5 mg) was injected intraperitoneally at the 45 th $\min$.

group B. The impression was gained that the rats injected with phentolamine were less able to perform exercise. Thus, out of 12 animals in group $\mathrm{C}$, one rat died after 12 min of swimming; and 2 other rats had to be removed from the tank after 7 to $13 \mathrm{~min}$ of exercise, because of obvious signs of distress.

A last sample of blood was obtained from the severed neck when each animal was killed by decapitation at the 70th min after the injection of GPATS.

2. Analytical methods. All samples of blood were collected in heparinized tubes. The volume and haematocrit of each sample were measured and the plasma

1 The commercial preparation of phentolamine also contained glucose, so that the rats in group $\mathbf{C}$ were injected intraperitoneally with $17.5 \mathrm{mg}$ glucose at the $45 \mathrm{th}$ min. This might explain, in part at least, why the plasma sugar concentration noticed at the 70 th min was slightly higher in group $\mathrm{C}$ than in group $\mathrm{B}$. period. This method has been previously described in greater detail [20].

\section{Results}

1. Initial period. As shown in Table 1, the administration of guinea-pig anti-insulin serum caused a rise in the plasma sugar concentration from $125 \pm 2$ to $277 \pm 7 \mathrm{mg} / 100 \mathrm{ml}$. During the same period $(0$ to 50 $\mathrm{min}$ ), the haematocrit fell and the volume of distribution of labelled albumin rose. Between the 2 nd and the 50 th min, insulin secretion amounted to $252 \pm 27 \mathrm{mU}$. All the values recorded during the initial period were of the same order of magnitude as those found during the same period in previous experiments $[18,20]$.

2. Experimental period. In the control rats of group A, the plasma sugar concentration continued to rise between the 50th and 70th min (paired difference: 
$+51 \pm 9 \mathrm{mg} / 100 \mathrm{ml})$. In the swimming rats of group B, no further change in plasma sugar concentration occurred during the experimental period (paired difference: $-11 \pm 16 \mathrm{mg} / 100 \mathrm{ml}$ ); so that their mean plasma sugar level at the 70 th min was significantly $(\mathrm{P}<0.02)$ lower than that of the control animals. In most of the rats of group $\mathrm{C}$, the plasma sugar concentration rose during the experimental period; however, their mean plasma sugar value at the 70 th $\mathrm{min}$ was not significantly different $(\mathrm{P}>0.2)$ from that of either the control (group A) or swimming (group B) rats.

Differences were also found among the 3 groups of rats in the evolution of the haematocrit and the distribution of albumin during the experimental period. Swimming prevented the further fall in haematocrit found in control rats, and caused a minor decrease in the albumin volume. Prior injection of phentolamine apparently minimized these haemodynamic effects of exercise.

The rate of insulin secretion was much lower in the swimming than in the control rats $(\mathrm{P}<0.001)$. Administration of phentolamine restored a normal secretory response. Thus, the mean rate of insulin secretion in group $\mathrm{C}$ was not significantly different $(\mathrm{P}>0.3)$ from that of group $\mathrm{A}$, and much higher $(P<0.005)$ than that of group $B$. Even when a restricted number of animals from group $B(n=5)$ and $C$ $(n=6)$ were selected in order to match their mean plasma sugar concentration at the 70 th $\min (279 \pm 25$ vs $282+28 \mathrm{mg} / 100 \mathrm{ml}$ ), the rate of insulin secretion during the experimental period remained significantly lower $(\mathrm{P}<0.02)$ in the rats of group $\mathrm{B}(66 \pm 15 \mathrm{mU})$ than in those of group $\mathrm{C}(199 \pm 37 \mathrm{mU})$.

\section{Discussion}

The present findings confirm that exercise inhibits insulin secretion, even when the beta cell is exposed to a sustained hyperglycaemia [18]. The role of endogenous catecholamines in this process was examined by combining the performance of exercise with the administration of an alpha-adrenergic blocking agent. In human subjects who perform exercise during an oral glucose tolerance test, the administration of phentolamine does not eliminate the insulin-lowering effect of the postprandial exercise [12]. However, the significance of this negative observation is obscured by the fact that the fall in the level of circulating insulin occurred concomittantly with a marked fall in the blood sugar concentration. In the rats injected with GPAIS, phentolamine abolished the inhibition of insulin secretion otherwise induced by exercise.

It is unlikely that the present changes in insulin secretion induced by exercise and phentolamine are due to concomittant variations in the plasma sugar concentration. Firstly, in the range of glucose concentration observed between the 50th and 70th min (259 to $347 \mathrm{mg} / 100 \mathrm{ml}$ ), insulin secretion in vitro occurs at a nearly maximal rate [6]. Secondly, in rats injected with GPAIS and compelled to swim, insulin secretion is markedly depressed even when the plasma sugar concentration remains at the same level as that found in control animals [18]. Thirdly, in the present experiments, a significant difference in the rate of insulin secretion of groups $\mathrm{B}$ and $\mathrm{C}$ was also recorded when animals from these groups were selected on the basis of a comparable degree of hyperglycaemia.

The most likely explanation for the present findings is that phentolamine abolished the exerciseinduced inhibition of insulin release by some direct effect upon the beta-cell. This interpretation is consistent with the hypothesis that exercise-induced inhibition of insulin secretion involves the activation of the alpha-adrenergic receptors of the beta-cell by endogenously released catecholamines.

Acknowledgements. This work was supported in part by a gxant from the Fonds National de la Recherche Scientifique (Brussels, Bulgium). G.R.B. is a Research Fellow (Department of Health and Welfare, Canada), on leave from the Department of Biology, University of Ottawa (Ottawa, Canada). We wish also to thank Mrs. M. Mahy for skilled technical assistance.

\section{References}

1. Cochran, B., Marbach, E.P., Poulcher, R., Steinberg, T., Gwinup, G.: Effect of acute muscular exercise on serum immunoreactive insulin concentration. Diabetes 15, 838-841 (1966).

2. Conard, V., Brunnengraber, H., Vanroux, R., Deschaepdrijver, A., Moermans, E., Franckson, J.R.M.: Influence of muscular exercise on glucose regulation. In: Biochemistry of Exercise, p. 114, ed. by J.R. Poortmans. Basel and New York: S. Karger 1969.

3. Federspil, G., Lefèvre, P., Luyckx, A.: Efffets d'un exercice musculaire continu (nage forcée) sur la gly. cémie et le taux plasmatique des acides gras libres, de l'insuline, et de la corticostérone chez le rat. Arch. Internat. Physiol. Bioch. 77, 778-786 (1969).

4. Gray, I., Beetham, W.P.: Changes in plasma concentration of epinephrine and norepinephrine with muscular work. Proc. Soc. Exptl. Biol. (N.Y.). 96, 636$638(1957)$.

5. Hoffman, W.S.: A rapid photo-electric method for the determination of glucose in blood and urine. J. biol. Chem. 120, $51-55$ (1937).

6. Malaisse, W., Malaisse-Lagae, F., Wright, P.H.: A new method for the measurement of in vitro pancreatic insulin secretion. Endocrinology 80, 99-108 (1967).

7. - - - Ashmore, J.: Effects of adrenergic and cholinergic agents upon insulin secretion in vitro. Endocrinology 80,975-978 (1967).

8. Mason, J.W., Wherry, F.E., Brady, J.V., Beer, B., Pennington, L.L., Goodman, A.C.: Plasma insulin response to $72-\mathrm{Hr}$. avoidance sessions in the monkey. Psychosom. Med. 30, $746-759$ (1968).

9. Nikkilä, E.A., Taskinen, M.R., Miottinen, T.A., Pelkonen, R., Poppius, H.: Effect of muscular exercise on insulin secretion. Diabetes 17, 209-218 (1968).

10. Porte, D., Jr.: A receptor mechanism for the inhibition of insulin release by epinephrine in man. J. clin. Invest. 46, 86-94 (1967).

11. Rasio, E.. Malaisse, W., Franckson, J.R.M., Conard, V.: Serum insulin during acute muscular exercise in normal man. Arch. int. Pharmacodyn. 160, 485-491 (1966). 
12. Reinheimer, W., Davidson, P.C., Albrink, M.J. Effect of moderate exercise on plasma glucose, insulin, and free fatty acids during oral glucose tolerance tests. J. Lab. clin. Med. 71, 429-437 (1968).

13. Schalch, D.S.: The influence of physical stress and exercise on growth hormone and insulin secretion in man. J. Lab. clin. Med. 69, 256-269 (1967).

14. Schwaerz, F., Ter Haar, D.J., Van Riet, H.G., Thijssen, J.H.H.: Response of growth hormone (GH), FFA, blood sugar and insulin to exercise in obese patients and normal subjects. Metabolism 18, 10131020 (1969).

15. Vendsalu, A.: Studies of adrenaline and noradrenaline in human plasma. Acta Med. scand. 49, suppl. 173, $1-123(1960)$.

16. Wright, P.H.: The measurement of insulin secretion: a review of current methods. Diabetes 17, $641-645$ (1967).

17. - Malaisse, W.J.: A simple method for the assay of guinea-pig anti-insulin serum. Diabetologia 2, 178188 (1966).

18. - - Effects of epinephrine, stress, and exercise on insulin secretion by the rat. Amer. J. Physiol. 214, $1031-1034$ (1968).

19. - - Reynolds, I. J.: The assay of partially neutralized guinea-pig anti-insulin serum. Endocrinology 81, $226-234$ (1967).

20. - Rivera-Calimlim, L., Malaisse, W.J.: Endogenous insulin secretion in the rat following injection of antiinsulin serum. Amer. J. Physiol. 211, 1089-1094 (1966).

\section{G.R. Brisson}

F. Malaisse-Lagae

W.J. Malaisse

Laboratoire de Médecine Expérimentale

115, Blvd. de Waterloo

B-1000 Bruxelles

Belgique 